\title{
Perbandingan Metode Brainstorming dan Metode Buzz Group dalam Pemberian KIE Kesehatan Reproduksi di Posyandu Remaja Puskesmas Aur Duri Kota Jambi
}

\author{
Ruwayda $^{1}$, Netti Herawati ${ }^{2}$ \\ 1,2Jurusan Kebidanan Poltekkes Kemenkes Jambi \\ Email : ruwayda@poltekkesjambi.ac.id
}

Submitted : 21/10/2020

Accepted: 06/01/2021

Published: 06/03/2021

\begin{abstract}
This study aims to analyze the effectiveness of the Brainstorming method and the Buzz Group method in providing IEC for reproductive health at the AurDuri Youth Health Center Posyandu in Jambi City in 2019. This research is a quasi-experimental study using a pretest and posttest design with control group design. The population is all adolescents who visit the posyandu as many as 60 people. Samples were taken using a total sampling technique of 30 treatment groups given the Brainstorming method and 30 people received the Buzz Group method. The research instrument was a questionnaire. Data analysis was carried out univariately to determine the frequency distribution, then bivariate analysis using the dependent t-test to see differences in knowledge before and after giving the brainstorming method and the Buzz Group method. The results showed that there was a difference in the mean increase in respondents' knowledge before and after using the brainstorming method with a mean difference of 1.233 and the difference in knowledge before and after using the buzz group method, namely 3.133. While the results of the analysis of differences in knowledge using the brainstorming method and the buzz group with a $p$ value of 0.000 , the difference in the mean value of 2.689 means that the buzz group method is more effective in increasing adolescent knowledge about reproductive health than the brainstorming method. It is suggested that the puskesmas should provide guidance to youth posyandu using a variety of varied methods such as buzz groups in providing IEC for reproductive health.
\end{abstract}

Keywords: brainstorming, buzz group, KIE

\begin{abstract}
Abstrak
Penelitian inibertujuan untuk menganalisis efektifitas metode Brainstorming dan metode Buzz Group dalam pemberian KIE kesehatan reproduksi di Posyandu Remaja Puskesmas Aur Duri Kota Jambi tahun 2019. Penelitian ini merupakan penelitian quasi eksperimen menggunakan rancangan pretest and posttest with control group design. Populasi adalah seluruh remaja yang berkunjung ke posyandu sebanyak 60 orang. Sampel diambil dengan menggunakan teknik total sampling sebanyak 30 orang kelompok perlakuan dengan diberikan metode Brainstorming dan 30 orang mendapatkan metode Buzz Group.Instrumen penelitian berupa kuesioner. Analisis data dilakukan secaraunivariatuntukmengetahui distribusi frekuensi selanjutnya analisis bivariat menggunakan uji t-test dependent untuk melihat perbedaan pengetahuan sebelum dan sesudah pemberian metode brainstorming dan metode Buzz Group. Hasil penelitian menunjukkan ada perbedaan rerata peningkatan pengetahuan responden sebelum dan sesudah menggunakan metode brainstorming dengan selisih nilai mean 1.233 dan perbedaan pengetahuan sebelum dan sesudah menggunakan methode buzz group yaitu 3.133. Sedangkan hasil analisis perbedaan pengetahuan yang menggunakan metode brainstorming dan buzz group dgn niali $\mathrm{p}$ value 0.000 perbedaan nilai mean 2.689 berarti metode buzz group lebih efektif dalam peningkatan pengetahuan remaja tentang kesehatan reproduksi dibanding metode brainstorming.Disarankan agar pihak puskesmas dapat melakukan pembinaan ke posyandu remaja menggunakan berbagai metode yang variatif seperti buzz group dalam pemberian KIE kesehatan reproduksi.
\end{abstract}

Kata kunci: brainstorming, buzz group, KIE 


\section{PENDAHULUAN}

Berdasarkan hasil survei kesehatan berbasis sekolah di Indonesia tahun 2015 (GSH) dapat terlihat gambaran faktor risiko kesehatan pada pelajar usia 12-18 tahun secara nasional sebanyak 41,8 \% laki-laki dan $4,1 \%$ perempuan mengaku pernah merokok, 32,82 \% diantara perokok pertama kali pada umur $<13$ tahun. Perilaku seks pra nikah tentunya memberikan dampak yang luas pada remaja terutama berkaitan dengan penularan penyakit menular seksual dan kehamilan tidak diinginkan serta aborsi

$$
\text { Hasil SDKI }
$$

menunjukkanbahwa pengetahuan remaja tentang kesehatan reproduksi belum memadai. Hanya $35 \%$ remaja perempuan dan 31,2 \% remaja laki-laki umur 15-19 tahun mengetahui bahwa perempuan dapat hamil dengan satu kali berhubungan seksual. Sebanyak 41,2 \% perempuan dan $55,3 \%$ laki-laki umur 15-19 tahun mengetahui cara penularan HIV-AIDS dapat dikurangi jika berhubungan seks hanya dengan seseorang yang tidak memiliki pasangan lain. $46 \%$ perempuan dan 60,8 \% laki-laki umur 15-19 tahun mengetahui bahwa penularan HIA/AIDS dapat dikurangi dengan menggunakan kondom. Hanya 9,9\% perempuan dan 10,6 $\%$ laki-laki umur 15-19 tahun memiliki pengetahuan komprehensif mengenaiHIV/AIDS (Kemenkes, 2015.

Remaja umur 15-19 tahun lebih suka berdiskusi/curhat mengenai masalah kesehatan reproduksi kepada teman sebayanya seperti yang ditunjukkan dalam SDKI (2012) dimana sebesar 57,1 \% lakilaki dan $57,6 \%$ perempuan berdiskusi/curhat mengenai kesehatan reproduksi dengan temannya. Sementara itu remaja umur 15-19 tahun menyukai bila sumber informasi kesehatan reproduksi diperoleh dari teman sebaya $(33,3 \%$ lakilaki dan $19,9 \%$ perempuan), guru $(29,6 \%$ laki-laki dan $31,2 \%$ perempuan), ibu $(12,7$ $\%$ laki-laki dan $40 \%$ perempuan) tenaga kesehatan (2,6\% laki-laki dan 35,7 \% perempuan). Jenis informasi yang sering diperoleh remjaa adalah bahaya penyalahgunaan NAPZA, bahaya minum minuman beralkohol dan tentang HIV AIDS termasuk penggunaan kondom untuk mencegah penularannya.

Berbagai metode dalam pemberian pendidikan kesehatan antara lain diskusi, ceramah, tanya jawab, konselor sebaya, curah pendapat dan lain-lain. Pada kelompok remaja khususnya di puskesmas PKPR (Pelayanan Kesehatan Peduli Remaja) metode yang paling sering digunakan adalah konselor sebaya dimana mereka dalam kelompok umur yang sama saling memberikan informasi seputar kesehatan reproduksi kepada teman sebayanya sehingga mereka bisa saling terbuka bercerita tentang masalah kesehatan reproduksinya (Kemenkes, 2015).

Metode brainstorming merupakan cara untuk mendapatkan banyak ide dalam waktu singkat. Model pembelajaran curah pendapat pada dasarnya merupakan model untuk mencari pemecahan masalah (prblem solving), meskipun dapat digunakan untuk tujuan penyusunan program, manual kerja, dan sebagainya (Suciati, dalam Suparman, 1998).

Metode diskusi Buzz Group menurut Suprijanto (2007:110), metode diskusi buzz group merupakan alat untuk membagi kelompok diskusi besar menjadi kelompok-kelompok kecil. Metode buzz group yaitu cara pembahasan suatu masalah yang dalam pelaksanaannya peserta dibagi dalam kelompok kecil antara 3-4 orang membahas suatu masalah yang diakhiri dengan penyampaian hasil pembahasannya oleh setiap juru bicara pada kelompok besar/kelas.

Pada posyandu remaja KIE yang diberikan mencakup pemberian informasi tentang organ reproduksi remaja, pubertas, proses kehamilan, menstruasi, KB, penyakit menular seksual, gender dan pendewasaan usia perkawinan. HIV/AIDS mencakup 
pemberian informasi seputar penularan, pencegahan dan gejala (Kemenkes, 2015).

Penelitian Wahyurin, dkk (2019) tentang pengaruh edukasi menggunakan metode brainstorming dan audio visual terhadap pengetahuan ibu menunjukkan rerata skor pengetahuan ibu saat pre test $6,44 \pm 1,65$ seangkan skor pada saat post test naik menjadi 7,38 $\pm 1,76$. Hasil uji beda menggunakan wilcoxon menunjukkan adanya perbedaan signifikan antara pengetahuan ibu sebelum dan sesuah intervensi menggunakan metode brainstorming.

Pelaksanaan Posyandu Remaja di Kota Jambi baru dimulai tahun 2018 dan baru terlaksana di satu Puskesmas yaitu Puskesmas Aur Duri. Sasaran remaja di Kota Jambi usia 10-18 tahun sebanyak 276.163 orang. Di Puskesmas Aur Duri sasaran remaja 3435 orang dan jumlah anggota posyandu remaja RT 07 sebanyak 70 orang $(0.02 \%)$ (Dinkes Kota Jambi, 2019).

Jumlah kunjungan remaja ke posyandu dalam tiga bulanterakhir mengalami penurunan dari 60 (100\%) menjadi $45(75 \%)$ pada bulan april 2019. Angka partisipasi kunjungan remaja ke posyandu menunjukkan minat remaja untuk berperan serta dalam posyandu, keikutsertaan dalam berbagai kegiatan dan pemeriksaan yang ada di posyandu tersebut. Menurunnya partisipasi remaja dikarenakan posyandu ini baru berdiri dan belum ada metode khusus dalam pemberian komunikasi Informasi dan edukasi (KIE) khususnya kesehatan reproduksi (Puskesmas Aur Duri, 2019).

\section{METODE PENELITIAN}

Penelitian ini merupakan penelitian analitik dengan rancangan quasy experiment two group pre and post test designbertujuan untuk menganalisis efektifitas metode Brainstorming dan metode Buzz Group dalam pemberian KIE kesehatan reproduksi di Posyandu Remaja
Puskesmas Aur Duri Kota Jambi tahun 2019. Lokasi penelitian dilakukan di Posyandu Aur Duri RT 07 Wilayah puskesmas Aur Duri Kota Jambi.Pelaksanaan penelitian dimulai dari bulan April s/d Oktober 2019.Populasi adalah seluruh remaja yang berkunjung ke posyandu sebanyak 60 orang. Sampel diambil dengan menggunakan teknik total sampling sebanyak 30 orang kelompok perlakuan dengan diberikan metode Brainstorming dan 30 orang mendapatkan metode Buzz Group.

Instrumen penelitian berupa kuesioner pengetahuan tentang Kesehatan Reproduksi. Analisis data dilakukan secara univariate untukmengetahui distribusi frekuensi selanjutnya analisis bivariat menggunakan uji t-test dependent untuk melihat perbedaan pengetahuan sebelum dan sesudah pemberian metode brainstorming danmetodeBuzz Group.

\section{HASIL DAN PEMBAHASAN}

Berdasarkan hasil penelitian, distribusi responden berdasarkan karakteristik responden dapat dilihat pada tabel 1 berikut:

Tabel1. Karakteristik Responden di Posyandu Remaja Puskesmas Aur Duri kota Jambi Tahun 2019

\begin{tabular}{llcc}
\hline \multirow{2}{*}{ No } & Karakteristik & \multicolumn{2}{c}{ Jumlah } \\
& & $\mathrm{f}$ & $\%$ \\
\hline 1 & Usia & & \\
& 10-12Tahun & 11 & 18.33 \\
& 13-15Tahun & 19 & 31.67 \\
& 16-18 Tahun & 30 & 50 \\
\hline 2 & Pendidikan & & \\
& < SMA & 11 & 18.33 \\
& $\geq$ SMA & 49 & 81.67 \\
\hline 3 & Jenis & & \\
& Kelamin & 39 & 65 \\
& Laki-laki & 21 & 35 \\
& Perempuan & & \\
\hline
\end{tabular}

Berdasarkan tabel 1 diketahui bahwa sebagian responden berada dalam rentang 
usia tahun 16-18 tahun sebanyak 30 orang (50\%), mayoritas memiliki pendidikan $\geq$ SMA sebanyak 49 orang $(81.67 \%)$, mayoritas berjenis kelamin laki-laki sebanyak 39 orang (65\%).

Hasil penelitian menunjukkan bahwa ada mayoritas yang hadir di Posyandu remaja adalah kelompok usia 1518 tahun, dan berjenis kelamin laki-laki.

Menurut hasil penelitian Goicolea et al (2016) ada perbedaan kualitas pelayanan remaja di klinik dan di tempat pelayanan yang ramah remaja, dimana remaja akan merasa lebih dekat dengan petugas. Menurut Mazur, et al (2018) perlua ada indikator dan alat yang digunakan untuk mengukur pelayanan kesehatan seksual yang ramah remaja,pelayanan sebaiknya menhargai dan menjaga privacy remaja sehingga mereka merasa aman dan nyaman dalam mendapatkan pelayanan kesehatan reproduksi.

Uji normalitas untuk mengetahui normalitas data pada 2 kelompok menggunakan methode Brainstorming dan Buzz Group diperoleh angka signifikansi > 0.05 sehingga data pada 2 kelompok normal dan selanjutnya dilakukan uji $\mathrm{t}$ test independent.

Distribusi responden berdasarkan penilaian pengetahuan responden sebelum dan sesudah menggunakan metode Brainstorming dapat dilihat pada tabel berikut:

Tabel 2 Distribusi Responden Berdasarkan Pengetahuan Sebelum dan sesudah menggunakan metode Brainstorming di posyandudi posyanduRemaja Kota Jambi

\begin{tabular}{|c|c|c|c|c|c|c|}
\hline Metode & $\begin{array}{l}\mathrm{Me} \\
\text { an }\end{array}$ & $\mathrm{N}$ & $\begin{array}{l}\text { Std } \\
\text { Dev } \\
\text { iasi }\end{array}$ & $\begin{array}{l}\text { Std } \\
\text { Err } \\
\text { or } \\
\mathrm{Me} \\
\text { an }\end{array}$ & $\begin{array}{l}\text { Correl } \\
\text { ation }\end{array}$ & Sig \\
\hline Sebelum & 10. & 3 & 1.92 & .35 & .563 & 0.0 \\
\hline $\begin{array}{l}\text { Brainsto } \\
\text { rming }\end{array}$ & 87 & 0 & 5 & 1 & & 01 \\
\hline Sesudah & 12. & 3 & 1.66 & .30 & & \\
\hline Brainsto & 10 & 0 & 8 & 5 & & \\
\hline
\end{tabular}

rming

Berdasarkan tabel 2 diketahui bahwa ada peningkatan signifikant nilai rerata pengetahuan responden sebelum dan sesudah pemberian metode Brainstorming (sig.0.001), dan selisih rata-rata nilai mean yaitu $1,23(10,87 \pm 12,10)$. Ada peningkatan skor pengetahuan responden sebelum dan sesudah pemberian metode Brainstorming sebesar 1,23.

Model pembelajran merupakan kerangka konsep yang menggambarkan prosedur pengorganisasian pengalaman belajar secara sistematis untuk mencapai suatu tujuan belajar. Menurut Eggan model pembelajran adalah strategi perspektif pembelajaran yang didesain untuk mencapai tujuan-tujuan pembelajaran tertentu sehingga model pembelajaran ini merupakan suatu perspektif tutor bertanggungjawab selalu pada tahap perencanaan, implementasi dan penilaian hasil pembelajaran (Trianto, 2007).

Distribusi responden berdasarkan penilaian pengetahuan responden sebelum dan sesudah menggunakan metode Buzz Group dapat dilihat pada tabel berikut:

Tabel 3 Distribusi Responden Berdasarkan Pengetahuan Sebelum dan sesudah menggunakan metode Buzz Group di posyandu Remaja Kota Jambi

\begin{tabular}{lllllll}
\hline $\begin{array}{l}\text { Metod } \\
\mathrm{e}\end{array}$ & $\begin{array}{l}\text { Mea } \\
\mathrm{n}\end{array}$ & $\mathrm{N}$ & $\begin{array}{l}\text { Std } \\
\text { Devi } \\
\text { asi }\end{array}$ & $\begin{array}{l}\text { Std } \\
\text { Erro } \\
\mathrm{r} \\
\text { Mea } \\
\mathrm{n}\end{array}$ & $\begin{array}{l}\text { Correlati } \\
\text { on }\end{array}$ & Sig \\
& & & & & \\
\hline $\begin{array}{l}\text { Sebelu } \\
\mathrm{m}\end{array}$ & 10.4 & 3 & 1.223 & .223 & .604 & 0.00 \\
$\begin{array}{l}\text { Buzz } \\
\text { Group }\end{array}$ & & 0 & & & & 0 \\
\hline $\begin{array}{l}\text { Sesud } \\
\text { ah }\end{array}$ & 13.5 & 3 & 1.431 & .261 & & \\
$\begin{array}{l}\text { Buzz } \\
\text { Group }\end{array}$ & & 0 & & & & \\
\hline
\end{tabular}

Berdasarkan tabel 3 diketahui bahwa ada peningkatan signifikant nilai rerata pengetahuan responden sebelum dan 
sesudah pemberian metode Buzz Group (sig.0.000), dan selisih rata-rata nilai mean yaitu $3,14(10,43 \pm 13,57)$. Ada peningkatan skor pengetahuan responden sebelum dan sesudah pemberian metode Buzz Group sebesar 3,14.

Penelitian yang dilakukan oleh wahyurin dkk (2019) tentang pengaruh edukasi stunting menggunakan metode brainstorming dan audio visual menunjukkan rerata skor pengetahuan ibu pada saat pre test adalah $6,44 \pm 1,65$ sedangkan skor pada post test naik menjadi $7,38 \pm 1,76$. Analisis menunjukkan terdapat perbedaan pengetahuan ibu yang signifikan mengenai stunting pada waktu sebelum dan sesudah pemberian edukasi gizidengan metode brainstorming dan audiovisual.

\section{Edukasi}

$$
\text { dengan }
$$

brainstorming mengharuskan responden terlibat aktif mengeluarkan pendapatnya metode menceritakan pengalamannya. Prinsip belajar dengan cara menghubunghubungkan dengan pengalaman atau perilaku lama (association stimulus) menyebabkan pesan akan lebih mudah diterima dan dipahami Metode brainstorming (curah pendapat). Prinsipnya sama dengan metode diskusi kelompok namun pada brainstorming, pemimpin kelompok memancing dengan satu masalah kemudian tiap peserta memberikan jawaban dan tanggapannya. Tanggapan dan jawaban tersebut ditampung dan ditulis dalam plifchart atau papan tulis. Sebelum semua peserta mencurahkan pendapatnya tidak boleh diberi komentar apapun dan oleh siapapun. Setelah semua mengeluarkan

Tabel 5. Perbedaan pada dua kelompok metode Brainstorming dan Buzz Group

\begin{tabular}{|c|c|c|c|c|c|c|c|c|c|}
\hline \multirow[t]{2}{*}{ Nilai Pengetahuan } & \multicolumn{2}{|c|}{$\begin{array}{l}\text { Levene's Test } \\
\text { for Equlity of } \\
\text { Var }\end{array}$} & \multicolumn{7}{|c|}{ t-test for equality of Means } \\
\hline & $\mathrm{F}$ & Sig & $\mathrm{t}$ & $\mathrm{df}$ & Sig & Mean & $\mathrm{SE}$ & & $6 \mathrm{CI}$ \\
\hline Buzz Group & 2.689 & 0.106 & 5.016 & 28 & 0.000 & 1.900 & 0.379 & $\begin{array}{l}\text { lower } \\
1.142\end{array}$ & $\begin{array}{l}\text { Upper } \\
2.658\end{array}$ \\
\hline Brainstorming & & & 5.016 & 19.422 & 0.000 & 1.900 & 0.379 & 1.140 & 2.660 \\
\hline
\end{tabular}

pendapatnya maka tiap anggota dipersilahkan memberikan komentar sehingga akhirnya terjadilah diskusi(Notoatmodjo, 2003).

Distribusi Rata-rata pengetahuan pada kelompok Metode Brainstorming danBuzz Group di Posyandu Remaja PKM Aur Duri Kota Jambi

Berdasarkan hasil penelitian diketahui ratarata terjadi peningkatan pengetahuan sebelum dan sesudah pemberian metode Brainstorming dan Buzz Group dapat dilihat pada tabel berikut:

Tabel 4. Analisis Perbedaan Rerata Pengetahuan Responden pada 2 Kelompok

\begin{tabular}{lllll}
\hline Metode & N & Mean & SD & $\begin{array}{l}\text { Std } \\
\text { Error } \\
\text { Mean }\end{array}$ \\
\hline Brainstorming & 30 & 1.23 & 1.695 & 0.310 \\
Buzz Group & 30 & 3.13 & 1.196 & 0.218 \\
\hline
\end{tabular}

Berdasarkan uji Independent Samples Test diketahui bahwa ada perbedaan pengetahuan remaja yang menggunakan metode Brainstorming dan Buzz group yaitu dengan skor $1,9(1,23 \pm 3,13)$. 
Berdasarkan tabel 5 diketahui ada perbedaan pengetahuan pada kelompok Brainstorming dan Buzz Group dengan $0.000(<\alpha 0,05)$ berarti ada perbedaan skor rerata pengetahuan pada metode Buzz Group sebanyak 3,13 dibandingkan metode brainstorming skor rerata 1,23. Dapat disimpulkan bahwa kedua metode samasama meningkatkan pengetahuan responden tentang kespro hanya saja ada ada perbedaan selisih rerata skor pengetahuan responden pada kelompok Buzz Group sebesar 1,9 dibandingkankelompok dengan metode Brainstorming.

Penelitian yang dilakukan Winancy dkk (2015) menunjukkan bahwa metode brainstorming efektif dalam meningkatkan pengetahuan suami mengenai tanda-tanda kehamilan. Hasil uji Mann-Whitney menunjukkan bahwa peningkatan nilai median pengetahuan pada kelompok buzz grup adalah lebih baik dibandingkan metode brainstorming terhadap pengetahuan ibu tentang tanda bahaya kehamilan, persalinan dan nifas.

Metode Diskusi Buzz Group menurut Suprijanto (2007:110), metode diskusi buzz group merupakan alat untuk membagi kelompok diskusi besar menjadi kelompokkelompok kecil. Terdapat dua jenis diskusi yang sering digunakan dalam menerapkan metode buzz group yaitu: pertama, teknik yang paling sering digunakan adalah membagi kelompok asal menjadi kelompok buzz yang terdiri atas 10 sampai 15 orang, bila kelompok asal anggotanya berjumlah 30 orang atau lebih. Sekretaris membuat catatan tentang ide-ide yang disarankan oleh anggota kelompok dan menyiapkan kesimpulan yang akan disampaikan kepada kelompok besar setelah diskusi Buzz group selesai. Kemudian sekretaris tiap kelompok, diminta untuk melaporkan hasil sebelum dibuka diskusi kelompok umum. Waktu yang dibutuhkan untuk diskusi Buzz group berkisar 10-20 menit tergantung pada topik yang dibicarakan.

\section{SIMPULAN}

Pada hasil penelitian dapat disimpulkan bahawa kedua metode dapat meningkatkan rerata skor pengetahuan repsonden pada dua kelompok, hanya saja pada metode Buzz group mempunyai selisih rerata skor pengetahuan 1,23 lebih tinggi dibandingkan rerata skor pengetahuan pada kelompok metode Brainstorming. Berdasarkan hasil penelitian dapat disimpulkan bahwa.

\section{SARAN}

Berdasarkan kesimpulan hasil penelitian maka dapat disarankan agar dapat mengembangkan kegiatan KIE dengan menggunakan berbagai metode yang bervariasi dan menerapkan berbagai metode dalam pemberian KIE kesehatan reproduksi bagi remaja di Posyandu sehingga dapat meningkatkan cakupan kunjungan remaja ke posyandu

\section{DAFTAR PUSTAKA}

BPS dan ORC Macro, 2012, Survei Demografi dan Kesehatan Indonesia. Calverton, Maryland, USA ORC Macro.

Badan Pusat Statistik, 2015 Data Kesehatan Indonesia, Jakarta

Dinas Kesehatan Kota Jambi, 2019, Data Sasaran Dinas Kesehatan Kota Jambi. Dinkes Kota Jambi

Puskesmas Aur Duri, 2019, Data Kunjungan Posyandu Remaja, Puskesmas Aur Duri Kota Jambi

Kementerian Kesehatan RI, 2009. Sistem Kesehatan Nasional , Jakarta Kemenkes RI

,2015. Petunjuk

Teknis Penyelenggaraan Posyandu Remaja, Jakarta Kemenkes RI , 2015. Survei

Kesehatan Berbasis Sekolah, Jakarta Kemenkes RI

2018. Buku

KIE kader Kesehatan Remaja, Jakarta, Kemenkes RI 
Laili, A, Riyanti, E \& Syamsulhuda, 2019. Faktor-faktor yang berhubungan dengan Praktik Pemanfaatan Pelayanan Kesehatan Peduli Remaja (PKPR) oleh Remaja di wilayah kerja Puskesmass Bandarharjo Kota Semarang. Jurnal Kesehatan Masyarakat Undip Vol 7 No1 Januari 2019.

http://ejournal3.undip.ac.id.index.php jjkm

Notoatmodjo S.2003.Pendidikan danperilakukesehatan,Jakarta Rineka Cipta

Nursalam, 2016, Metode Penelitian Keperawatan, Salemba Medika Jakarta

Roestiyah, 2010, Strategi Belajar Mengajar, Jakarta Rineka Cipta
Suprijanto, 2007, Pendekatan Orang Dewasa dari Teori Hingga Aplikasi,Jakarta Bumi Aksara

Trianto 2007, Model-Model Pembelajaran Inovatif Berorientasi Konstruktif, Jakarta Penerbit Prestasi Pusktaka

Triono, 2007, Mendesain Model Pembelajaran Inovatif Progresif, Jakarta PT Kencana

Winancy W, Raksanagara AS, uadah Y/ 2015, Perbandingan penerapan metode Inovatif Progresif, JakartaPT Kencana brainstorming dan buzz group terhadap pengingkatan pengetahuan suami ibu hamil tentang tanda bahaya kehamilan,persalinan dan nifas (studi kasus di Bogor). Southeast Assian J Midwifery 